\title{
PERSONALITY TRAINER CHARACTERISTICS AS JOB SATISFACTION PREDICTORS
}

\author{
Ivanović Miroljub ${ }^{1}$ \& Ivanović Uglješa ${ }^{2}$ \\ ${ }^{1}$ Professional studies academy for kindergarten teachers education, Sremska Mitovica, Serbia \\ ${ }^{2}$ Faculty of sport management, Belgrade, Serbia
}

DOI: $10.5550 /$ sgia. 1002001

ORIGINAL SCIENTIFIC PAPER

\section{SUMMARY}

The main aim of this research was to define the calculated personality five big characteristics model for the total job satisfaction The Big Five Inventory (BFI, John, Donahue and Kentle, 1991), as well as the 9 aspects of job satisfaction, which were measured on the Job Satisfaction Survey scale (JSS, Spector, 1985). Except the personality characteristics, as the predictor type, the trainer variables of gender and work experience were researched. The examinees sample consisted of 126 football, basketball, volleyball and handball trainers in permanent employment on the territory of Belgrade. According to the achieved results of the multivariate covariance analysis and hierarchy multiple regression analysis the conclusion, that for the relevant prediction of trainer job satisfaction distinguish the trainers who have high scores on the pleasant and neuroticism scales, was made. For the satisfactory prediction in some aspects of trainer job the three personality trainer pleasantness, conscientiousness and neuroticism characteristics are separated from the whole. The categorical trainer variables (gender and working experience) - as predictorsdidn't show statistically significant.

Key words: sport trainers, Big Five model, trainer job satisfaction.

\section{INTRODUCTION}

Personality is good predictor of those behaviors, which are impossible to predict using the general mental abilities, knowledge, adroitness and concrete situations (Barrick \& Mount, 2005; Ones, Viswesvaran \& Dilchert, 2005). Individual's behavior is determined by his personality characteristics and situational factors, which are changeable during the time. In order to exchange and predict job satisfaction, knowledge about individual's personality characteristics and his surroundings is required. For that latent dimensions excite growing interest of researches.

McCrae \& Costa (1991) have made a model called personality Big Five model, which assumes existence of five following basic personality dimensions: (I) extraversion, (II) neu- roticism, (III) pleasantness, (IV) conscientiousness and (V) openness to experience. Main virtue of this model is strong empirical foundation and conceptual wideness. So "Big Five" becomes one of the leading models in personality psychology during the XX century. In this work, authors started from the fact that the afore-mentioned theory has attracted great researchers' attention in the recent decade. There is a great deal of literary agreement about "Big Five" model application convenience in the researches, which are related to the work surrounding. Only some hitherto studies from the mentioned domain will be brought here.

According to Wrightov's (2006) research, the term job satisfaction shows social attitude, which involves cognitive and conative dimensions and feelings. Paul Spector (1997) has 
empirically established theoretical base job satisfaction, defining it as "what personality feels towards his/her job and uncorresponding occurrence of job types. Job satisfaction is, to some extent, also an indicator of job stimulus of total job situation.

Development of "Big Five" model personality dimensions contributed to the researches and connection of personality characteristics with job satisfaction variables.

At the beginning of the XX century, Tailor \& Gilbert began research of the job satisfaction phenomenon (Wright, 2006), supposing that the idea of scientific management largely reduces the body fatigue amount and contributes to the people's sole satisfaction, which is necessary to complete the job tasks. According to these authors' researches, it is inevitable that worker, being in accordance with the idea of scientific management in the shortest time interval, performs the tasks, for which he will be greatly financially awarded. Their initial thought was that if a worker adopts general principles of scientific management as his own, expanding minimum physical and psychological strength, he will achieve the best results and gain maximal monetary compensation. It will lead to his job satisfaction. Therefore, according to the scientific management theory, monetary compensation is relevant for improving the job satisfaction degree of individuals.

Individual behavior is determined by his personality characteristics and situational factors. Great number of authors has researched linear job satisfaction correlation and some personality dimensions. Some factors significance related to this phenomenon can change during the time. However, some researches indicate that personality dimensions have certain stabilizing role in the job satisfaction evaluation, so latent personality dimensions arouse greater researcher's interest.

Significant researches number checked the Big Five model validity on the different world wide populations. Validity of five big factors was verified to a great extent.

According to the Đurić-Jočić and collaborator's researches (2004), Big Five model, assumes that characteristics of a person can be quantified using the self-evaluation question- naire and that they significantly contribute to opinion, emotions and human posture.

Judge, Heller \& Mount's researches (2003), has drawn attention to some personality characteristics of Big Five model, which are statistically significant predictors of job satisfaction. Maximal correlation has been determined between neuroticism and job satisfaction $(\mathrm{r}=.-38)$, which indicates that these people are prone to experiencing bad feelings. Also, according to the same authors' findings in the study, conscientiousness is the second dimension, which is in the significant positive mutual relation with the job satisfaction $(\mathrm{r}=.31)$. It is expected that if the examinees achieve significant results on the conscientiousness variable, they will develop high-quality work characteristics, work appreciation and inner business success. There is a greater job satisfaction.

Furnam \& Zacherl (1986), Watson \& Slack (1993), Watson \& Clark (1997) are, according to the Judge's research (1999), singled out the extraversion personality characteristic as significant predictor job satisfaction variable.

McCrae \& Costa (1991) have defined pleasantness variable as significant job satisfaction predictor. People, who achieve significant results on this latent dimension, are stimulated for accomplishing significant level of emotional connection with their collaborators, and there-fore for accomplishing greater extent of job satisfaction.

On the sample of 300 teachers and collaborators working at the Universities in Novi Sad and Belgrade, Matanović (2009) has researched predictive values of personality characteristics of Big Five model for the total job satisfaction as well as 9 job satisfaction aspects, which were measured by Job Satisfaction Survey scale. Apart from personality characteristics, as categorical predictors, gender and university work experience variables have also been examined. According to the achieved results, it is concluded that, as significant predictors of total job satisfaction, the pleasantness and neuroticism characteristics are distinguished, while categorical variables have not shown as significant predictors. For the prediction of some job aspects satisfaction the following issues are separated: pleasantness, conscientiousness and neuroticism, being: pleasantness 
for aspects such as: improvement, management, job nature, communications and cooperatives; conscie-ntiousness for aspects such as: cooperatives, benefits and rewarding and neuroticism for aspects such as: management, job nature, communications, cooperatives, benefits and rewarding.

The main aim of this research is to check predictive value of dimension personality variance (as predictor), gender and trainer work experience and some occurrence of trainer job types satisfaction (as criterion).

\section{METHOD}

\section{Sample and procedure}

The research has been conducted on the representative sample of 126 examinees $(\mathrm{M}=33.7$ years; $\mathrm{SD}=11.06)$ in the following football, basketball, volleyball and handball clubs on the territory of Belgrade city: FC "Rad", YFC "Belgrade", BSC and FC " $\mathrm{Cu}$ karicki Stankom"- Jelen Super Serbian League; BC "FMP", BC "Mega vizura", VC "Belgrade" and BC "Superfund BP"- A basketball league - VC "Obilic", VC "Partizan" and VC "Crvena Zvezada" - I volleyball league; HC "Crvena Zvezda", HC "Kolubara" and HC "Partizan" - Super handball league.

The questionnaires have been given to the football, basketball, volleyball and handball trainers, who are permanently employed. They have been administrated to the examinees before the training, with the presence of the examiners. Before the examination, the examinees have been read and interpreted the questionnaire manual.

The examination was completely voluntary and anonymous and it was conducted in the September of 2010.

\section{Instruments}

In this empirical research two measuring instruments have been applied: a) Job Satisfaction Survey (JSS, Spector, 1985) and b) The Big Five Inventory (BFI, John, Donahue \& Kentle, 1991).

Each particle, actually the claim about 9 job satisfaction aspects has been evaluated by the
Job Satisfaction Survey questionnaire, which contains 36 items, with six-scale of Likert's type. Achieved results, from this scale, enable 10 independent calculations such as: 9 job satisfaction aspects (pay, advancement, management, benefits, rewarding, work procedures, cooperatives, job nature and communications), i.e. the achieved examinees results on the individual subscales, while 10 . achieved result- general measure job satisfaction - presents the amount obtained by results addition of all test entries.

Using the Cronbach-alfa coefficient (Cronbach, Glaser, Nanda \& Rajaratnam, 2004) it is determined that relatively high inner consistency of this 36-item Scale $(\alpha>.89)$, and the objectivity of some sub-scale values goes within ranges of .64 to .85 .

The second applied measuring instrument, The Big Five Inventory, by which the personality dimensions are evaluated according to the "Big Five" Model, consisted of five-scale of Likert's type, which is separated into 44 claims with 5 following sub-scales: extraversion, pleasantness, conscientiousness, neuroticism, openness to experience. The examinees have the task to mark each continuous predictor, actually the five-factor personality model claim, using the number, which suits its personality characteristics self-description on the five-scale from 1 to 5 (1 - I do not agree at all, 5 - I totally agree). The total result is formed as linear evaluation combination.

44-item scale objectivity of Five big dimension personality model, is $\alpha=.87$, which is satisfying reliability measure of inter metric applied measuring instrument characteristics.

In this research, calculated coefficient of inner Cronbach $\alpha$ consistency, for both applied measuring instruments, does not immensely differ from findings, which Matanovic achieved (2009).

Apart from the two mentioned measuring instruments, general data examinees' testing has been conducted by the help of two predictor categorical variables: gender and trainer work experience in a club. The second variable has 5 following ranges: $1-5,6-10,11-15,16-$ 20 and $21-30$ years and more trainer experience.

Data processing has been based on the co- 
variance analysis. For the quantitative and qualitative differences definition, actually significant predictors for some satisfaction trainer job aspects, the multifactor analysis covariance (MANCOVA) has firstly been applied, and then also the analysis variance (ANCOVA) for every of satisfaction trainer job aspects.

Statistic program MedCalc software (version 8.1.0.0 for Windows, MedCalc) has been used for data processing.

\section{RESULTS}

In the Table 1 the univariance effect of predictor variables for total trainer job satisfaction is visualized.

Conducted analysis draws attention to the fact that according to the level of statistically F-test significance, i.e. the variance predictor variable relation of total trainer job satisfaction, separates the personality pleasantness and neuroticism dimensions.

TABLE 1.

AKOV A of continuous predictor variables on total trainer job satisfaction

\begin{tabular}{lrcrrrr}
\hline & SS & df & \multicolumn{1}{c}{ MS } & \multicolumn{1}{c}{ F } & \multicolumn{1}{l}{ p } & \multicolumn{1}{c}{$\beta$} \\
\hline Extraversion & 57.24 & 1 & 56.36 & .10 & .95 & .04 \\
\hline Pleasantness & 5176.04 & 1 & 5937.02 & 11.46 & $\mathbf{. 0 1}$ &. $\mathbf{2 9}$ \\
\hline Neuroticism & 5108.66 & 1 & 5421,54 & 8.35 & $\mathbf{. 0 2}$ & $\mathbf{- . 2 5}$ \\
\hline Openess & 148.29 & 1 & 149.22 & .32 & .75 & .02 \\
\hline Conscientiousness & 1382.27 & 1 & 1291.24 & 1.98 & .15 & -.09 \\
\hline Gender & 348.27 & 1 & 397.23 & .18 & .63 & .08 \\
\hline Sport experience & 301.27 & 1 & 311.06 & .49 & .73 & .05 \\
\hline
\end{tabular}

Note: $\mathrm{R}=.46 ; \mathrm{R}^{2}=.21 ; \mathrm{F}=1.94 ; \mathrm{p}=.00$

Legend: $\mathbf{R}$ - multiple correlation coefficient, $\mathbf{R}^{\mathbf{2}}$ - determination coefficient,

$\mathbf{F}$ - Fisher's test for statistically significance determination, $\mathbf{P}$ - statistical significance level of multivariate test, $\mathbf{S S}$ - arithmetic mean, $\mathbf{d f}$ - degrees of freedom, MS - middle square of corrected arithmetic mean, $\mathbf{p}$ - level of multivariate test statistic significance, $\boldsymbol{\beta}$ - beta standardize partial contribution.

TABLE 2.

\section{Covariance predictor variable analysis}

\begin{tabular}{lrrl}
\hline & $\begin{array}{r}\text { Wilks' } \\
\text { Lambda }\end{array}$ & F & p \\
\hline Extraversion - E & .923 & 1.438 & $\mathbf{. 0 9}$ \\
\hline Pleasantness & .866 & 3.125 & $\mathbf{. 0 1}$ \\
\hline Conscientiousness - C & .885 & 2.164 & $\mathbf{. 0 0}$ \\
\hline Neuroticism - N & .953 & 1.956 & $\mathbf{. 0 5}$ \\
\hline Openess to experience - O & .956 & 1.429 & .12 \\
\hline Gender & .937 & 1.562 & .07 \\
\hline Sport experience - SS & .926 & .657 & .65 \\
\hline
\end{tabular}

Legend: Wilks' $\lambda$ - Wilk's lambda test, $\mathbf{F}$ - Fisher's test for statistically significance determination, $\mathbf{p}$ - level of statistical significance.

In order to gain the knowledge, if some personality characteristics and categorical variables, gender and trainer work experience in a club contribute to the differences of 9 job satisfaction aspects, the multifactor covariance analysis (MANCOVA) has been applied.
Covariance analysis results on the level of individual variables (Table 2) show that three personality dimensions: pleasantness $(\mathrm{F}=1.438, \mathrm{p}<.01)$, conscientiousness $(\mathrm{F}=2.164$, $\mathrm{p}<.00)$ and neuroticism $(\mathrm{F}=1.956, \mathrm{p}<.05)$ are separated from the five factor personality 
model whole, and in that manner present statistically significant continuous predictor of so-me trainer job satisfaction aspects, along with the error less than 5\% (Table 3). Further analysis of F-test - relation variability value in the system of categorical predictor variables (gen-der and trainer work experience in a club) - has not shown statistically significant differences between arithmetic means.

TABLE 3.

MANCOVA - model significance

\begin{tabular}{lccccccc}
\hline & $\mathrm{R}$ & $\mathrm{R}^{2}$ & $R_{c}^{2}$ & $\mathrm{df}$ & \multicolumn{1}{l}{$\mathrm{MS}$} & $\mathrm{F}$ & $\mathrm{p}$ \\
\hline Pay & .53 & .26 & .11 & 33 & 42.14 & 2.09 & $\mathbf{. 0 2}$ \\
\hline Advancement & .48 & .29 & .09 & 31 & 25.16 & & $\mathbf{. 0 0}$ \\
\hline Management & .54 & .24 & .13 & 32 & 34.34 & 2.17 & $\mathbf{. 0 3}$ \\
\hline Benefits & .39 & .17 & .12 & 34 & 28.46 & 2.11 & $\mathbf{. 0 1}$ \\
\hline Work procedures & .41 & .19 & .07 & 35 & .05 & 1.59 & .26 \\
\hline Cooperatives & .52 & .18 & .12 & 33 & 25.01 & 1.97 & $\mathbf{. 0 5}$ \\
\hline Job nature & .63 & .29 & .22 & 35 & 28.14 & 4.01 & $\mathbf{. 0 0}$ \\
\hline Communication & .39 & .20 & .11 & 35 & 19.88 & 2.03 & $\mathbf{. 0 0}$ \\
\hline Rewarding & .38 & .23 & .09 & 35 & 28.26 & 1.47 & $\mathbf{. 0 3}$ \\
\hline
\end{tabular}

Legend: R.- multiple correlation coefficient, $\mathbf{R}^{2}$ - determination coefficient, $R_{c}^{2}$ corrected determination coefficient, $\mathbf{d f}$ - degrees of freedom, MS - middle square, $\mathbf{F}$ - Fisher's test for statistically significance determination, $\mathbf{p}$ - level of statistical significance.

TABLE 4.

Predictor variables significance for some trainer job satisfaction prediction

\begin{tabular}{|c|c|c|c|c|c|c|c|c|}
\hline & & $\mathrm{E}$ & $\mathrm{P}$ & $\mathrm{N}$ & $\mathrm{S}$ & $\mathrm{O}$ & SEX & RS \\
\hline \multirow{3}{*}{ Anvancement } & $E$ & 4.11 & & & & & & \\
\hline & $\mathrm{P}$ & .06 & & & & & & \\
\hline & $\beta$ & .12 & & & & & & \\
\hline \multirow{3}{*}{ Management } & $\mathrm{E}$ & 9.24 & 4.97 & & & & & \\
\hline & P & ,01 & .00 & & & & & \\
\hline & $\beta$ & .32 & -.21 & & & & & \\
\hline \multirow{3}{*}{ Benefits } & $\mathrm{E}$ & & 9.03 & 4.73 & & & & \\
\hline & P & & .05 & .02 & & & & \\
\hline & $\beta$ & & -.12 & -.19 & & & & \\
\hline \multirow{3}{*}{ Rewarding } & E & & & 10.67 & 5.97 & & & \\
\hline & $\mathrm{P}$ & & & .02 & -01 & & & \\
\hline & $\beta$ & & & -.18 & -.24 & & & \\
\hline \multirow{3}{*}{ Collaborators } & $\mathrm{E}$ & & 30.14 & 5.16 & 5.87 & & & \\
\hline & $\mathrm{P}$ & & .00 & .05 & .04 & & & \\
\hline & $\beta$ & & .41 & -.17 & -.21 & & & \\
\hline \multirow{3}{*}{ Job nature } & $\mathrm{E}$ & & 22.35 & 4.15 & & & & \\
\hline & $\mathrm{P}$ & & .01 & .04 & & & & \\
\hline & $\beta$ & & .19 & -.13 & & & & \\
\hline
\end{tabular}

Legend: F - Fisher's test for statistically significance determination, $\mathbf{p}$ - level of statistical multivariate test significance, $\boldsymbol{B}$ - beta standardize coefficient beta, $\mathbf{E}$ - extraversion, $\mathbf{P}$ - pleasantness, $\mathbf{N}$ - neuroticism, $\mathbf{O}$ - experience openness, $\mathbf{S E X}$ - gender, RS - trainer working experience. 
Statistically significant predictor variables of some job satisfaction standpoints are illustrated in the table 4.

Reviewing the F-relation, statistically significance level and Beta coefficient, it is established that for the statistically significant prediction of job satisfaction standpoint, which is determined as advancement, the personality pleasantness dimension is an exception. Thereafter, two personality characteristics (pleasantness and neuroticism) have separated from the five factor personality model whole as significant predictor variables for the following four job satisfaction aspects: management, collaborators, job nature and communications.

Calculated Beta coefficient stresses that the examined trainers with the positive values on the pleasantness scale and negative results on the neuroticism scale lead to the higher level of trainer job satisfaction aspect - management.

Other than that, trainer job satisfaction aspects such as: collaborators, benefits and rewarding, can be predicted according to the personality characteristic - conscientiousness.

However, it can also be established, that the two predictor categorical variable variability (gender and trainer work experience in a club) are not statistically significant for the prediction of some trainer job satisfaction aspects. Furthermore, with the analyzed dimension personality "Five Big" model variance prediction of the pay and work procedure cannot be achieved, as trainer job satisfaction aspect can.

In this research, calculated significance Ftest level is in accordance with the Matinić's results (2009).

\section{DISCUSION}

This work tends to define variability, i.e. quadratic value exception from the predictor total trainer job satisfaction variable arithmetic mean and its satisfaction aspects, according to the personality characteristics of "Big Five" model variables and two predictor categorical variables (gender and trainer work experience in a club).

The five factor model structure showed that the personality pleasantness dimension and neuroticism are the significant predictor of total trainer job satisfaction variable, actually examinees who achieve higher results on the neuroticism scale reached higher trainer job satisfaction degree, while examinees with high neuroticism have lower trainer job satisfaction degree. Apart from that, trainers, who have high values on the pleasantness scale, develop friendly relationship with sportsmen and their collaborators. In reference to the fact that they are friendly with sportsmen, they will, taking everything into consideration, successfully find their place in the work surroundings, so we can be quite sure that they, in spite of the high trainer job satisfaction, would not have any obstacles in the communication with sportsmen and collaborators.

Regardless the fact that there are not any congruent researches on the trainer population, distinguished personality characteristics pleasantness presents significant trainer job satisfaction predictor, for high result on the pleasantness scale probably causes high inner or intrinsic motif for achievement and emotional trainer stability, intense intimacy with sports-men and collaborators, or grater trainer job satisfaction.

Contrary to them, it is assumed that trainers, who have high values on the neuroticism scale, are prone to negative feelings manifestation during the training process. They are quickly enraged, usually have disagreements with players and explosively oppose, which indicates to conflict behaviors, which differ from the social-educational system of rules during the training process. Thus, this trainer population is probably prone to trainer job dissatisfaction advancement. Within the scope of five factors model three personality dimensions (pleasantness, conscientiousness and neuroticism), have been manifested as significant predictors of some trainer job satisfaction aspects.

A personality characteristic, pleasantness, is significant predictor for advancement aspect, but also for management, job nature, and communication and collaborators aspect prediction. Trainers, who achieve high results on the pleasantness personality dimension, will lead satisfaction to a higher level by the help of mentioned occurrence trainer job satisfac- 
tion types. Trainer, who is good-tempered and ready to collective work, is prone to balance in every way, in order not to enter into a conflict during the interpersonal relations. Therefore, the trainer, with the high results on the pleasantness scale, will most probably have high values from the point of job, and of advancement as well. Trainers, who achieve strikingly high results on the scale of pleasantness, adopt a system of rules independently from their understanding. Therefore, they will lead management satisfaction to a higher level - since they believe they should treat their sportsmen needs - adopt their system of rules, perfectly agree with them, without any analysis or evaluation, since they believe that most sportsmen are good. They, as pleasant persons, who seek harmony and interpersonal closeness, will achieve significant satisfaction level on this management aspect.

Neuroticism personality dimension is excepted as the most common predictor satisfaction variable of some trainer job standpoints. Trainers, who achieve significant results on this scale, will, in an organization sense, have lower satisfaction of trainer job occurrence types, which are marked as: management, job nature, communication, collaborators, benefits and rewarding. This entire means that they hardly achieve harmony in the existing circumstances, they are usually in a conflict with their sports-men, collaborators and their reputation. Furthermore, they need much more time to recover from a psychic experience, which over-burdens and exhausts organism, contrary to trainer who have low result values on this scale. They are very easily opposed, prone to great excitements and negative feelings in their life domains. So it is obvious that they will be on the lower trainer job satisfaction level, for they will, under the trainer process structure, express negative feelings.

According to the achieved results on the conscientiousness scale job aspects satisfaction can be predicted as: collaborators, benefits and rewarding. Trainers, who achieve significant results on this scale, will have lower satisfaction level of mentioned job types, since they are characterized by responsibility, persistence and motivation for achieving their goals. It is assumed that these trainers, for their inlay enormous work, expect corresponding rewards. Apart from that, it can be sensed that trainer, who achieved significant result on the conscientiousness scale, is also mostly concentrated on an individual, and less on a collective training. Consequently, trainer of this kind manifests lower satisfaction level in occurrence satisfaction type - collaborators. It is most probable that he will see his collaborators as potential danger in achieving his goals in a sport club.

It is unusual that personality extraversion dimension has not manifested as statistically significant trainer job satisfaction predictor, although Judge and collaborators $(1999,2002)$ have excepted it from the personality characteristics of "Five Big" model whole as one of the most important predictor variables. Also, trainer job aspects (pay and work procedures) along with predictor categorical gender and trainer work experience in club variables, have not shown to be statistically significant, and so they could not been prognosticated by the help of researched predictors.

\section{CONCLUSION}

According to the research findings, on the specific sample football, basketball, volleyball and handball trainers, who are permanently employed, variability prognostication, in predictor variables personality dimension "Five Big" model system and trainer job satisfaction criterion, is defined.

Achieved results of this research indicate to the fact that three personality five factor model dimensions (pleasantness, conscientiousness and neuroticism) statistically significant for the trainer job satisfaction and some of its aspects prognostication. In addition to this, results indicate to the conclusion that sport trainers, who achieve significant results on the neuroticism and conscientiousness scales, lead trainer job satisfaction and some of its aspects to a lower level, while trainers, who achieve significant results on the scale of pleasantness, lead trainer job satisfaction to a higher level.

Since the examinees sample is not sizeable, it could be interesting to examine the predictive validity of these applied continuous and 
categorical variables on the representative sample of trainer population and other sports.

\section{REFERENCE:}

Barrick, M.R. \& Mount, K.M. (2005). Yes, Personality Matters: Moving on to More Important Matters. Human Performance, 18(4), pp. 359-372.

Cronbach, L.J., Glaser, G.C., Nanda, H. \& Rajaratnam, N. (1972). The dependability of behavioral measurements: Theory of generalizability for scores and profiles. New York: Wiley.

Cukić, B. (2005). Organizational behavior in roles and groups. [Organizaciono ponašanje $u$ ulogama i grupama. In Serbina.]. Kruševac: Fakultet za industrijski menadžment, Izdavački centar za industrijski menadžment plus.

Djurić-Jočić, D., Džamonja-Ignjatović, T. \& Knežević, G. (2004). NEO PI-R application and interpretation. [NEO PI-R, primena i interpretacija. In Serbian.] Beograd: Centar za primenjenu psihologiju.

Ilies, R. \& Judge, T. (2003). On the heritability of job satisfaction: The mediating role of personality. Journal of Applied Psychology, 88, pp. 750-759.

John, O.P., Donahue, E.M. \& Kentle, R.L. (1991). The Big Five Inventory - Versions 44 and 54. Berkley, CA: University of California, Berkley, Institute of Personality and Social Research.
Judge, T.A. Higgins, C.A. Thoresen, C.J. \& Barrick, M.R. (1999). The Big Five personality traits, general mental ability, and career success across the life span. Personnel Psychology, 52, pp. 621-652.

Judge, T., Heller, D. \& Mount, M. (2002). Five-factor model of personality and job satisfaction: A meta-analysis. Journal of $A p$ plied Psychology, 87, pp. 530-541.

Matanović, J. (2009). Personality traits as predictors of job satisfaction [Osobine ličnosti kao prediktori zadovoljstva poslom. In Serbian.]. Primenjena psibologija, 2(3), pp. 327338.

McCrae, R.R. \& Costa, P.T. (1991). Adding liebe und arbeit: The full fivefactor model and well-being. Personality and Social Psychology Bulettin, 17, pp. 227-232.

Ones, D.S., Viswesvaran, C. \& Dilchert, S. (2005). Personality at Work: Raising Awareness and Correcting Misconceptions. $\mathrm{Hu}$ man Performance, 18(4), pp. 389-404.

Spector, P.E. (1985). Measurement of human Service Staff Satisfaction: Development of the Job Satisfaction Survey. American Journal of Community Psychology, 13, pp. 693-713.

Spector, P.E. (1997). Job Satisfaction: Application, Assessment, Causes and Consequences. Thousand Oaks, California, USA: Sage Publications.

Wright, Th.A. (2006). The emergence of job satisfaction in organizational behavior, A historical overview of the dawn of job attitude research. Journal of Management History, 12, pp. 262-277.

Received: September, $27^{\text {th }} 2010$ Accepted: December, $3^{\text {rd }} 2010$

Correspodence to: Miroljub Ivanović, $\mathrm{PhD}$ Professional studies academy for kindergarten teachers education Zmaj Jovina 29 22000 Sremska Mitrovica Serbia

Phone: +381 22621864 +3816917 77019

Fax: +3812262 2231

E-mail: miroljub.ivanovic@gmail.com 


\title{
OSOBINE LIČNOSTI TRENERA KAO PREDIKTORI ZADOVOLJSTVA POSLOM
}

\author{
Ivanović Miroljub ${ }^{1}$ i Ivanović Uglješa ${ }^{2}$ \\ ${ }^{1}$ Visoka škola strukovnih studija za obrazovanje vaspitača, Sremska Mitrovica, Srbija \\ ${ }^{2}$ Fakultet za menadžment u sportu, Beograd, Srbija
}

Osnovni cilj ovog istraživanja je ispitati preditiktivnu vrijednost dimenzija ličnosti, pol i radni staž trenera i zadovoljstva trenerskog posla (kao kriterijum).

Uzorak ispitanika činilo je 126 trenera $(\mathrm{M}=33,7$ godina; $\mathrm{SD}=11,06)$ u stalnom radnom odnosu sa teritorije grada Beograda iz 14 spo-rtskih klubova i to: FK „Rad“, OFK „Beograd“, BSK i FK „Čukarički Stankom“ Jelen super liga Srbije; KK „FMP“, KK „Mega vizura“, OKK „Beograd“ i KK „Superfund $\mathrm{BP}^{\prime}$ - A - košarkaška liga; OK „Obilić“, OK „Partizan“ i OK „Crvena zvezda“ - Prva odbojkaška liga; RK „Crvena zvezda“, RK „Kolubara“ i RK „Partizan“ - Super rukometna liga.

U istraživanju su korišćeni slijedeći mijerni instrumenti: a) Skala Job Satisfaction Survey (JSS, Spector, 1985) i b) Skala The Big Five Inventory (BFI, John, Donahue \& Kentle, 1991), kao i dvije prediktorske varijable: pol i radni staž trenera u klubu. Metodom Kronbah-alfa koeficijenta (Cronbach, Glaser, Nanda and Rajaratnam, 2004) utvrđena je relativno vi-soka unutrašnja konzistentnost Skale Job Sati-sfaction Survey $(\alpha>0,89)$, kao i skale modela „Pet velikih“ dimenzija ličnosti $(\alpha=0,87)$, što predstavlja zadovoljavajuće mjere pouzdanosti internih metrijskih karakteristika za oba primijenjena mjerna instrumenta.

Definisanje značajnih prediktora za pojedine aspekte zadovoljstva trenerskim poslom urađeno je primjenom višefaktorske analize kovarijanse (MANCOVA), dok je za svaki od aspekata zadovoljstva trenerskim poslom primijenjena analiza varijanse (ANCOVA). Za obradu podataka, korišćen je statistički program MedCalc software (version 8.1.0.0 for Windows, MedCalc).

Rezultati F-testa pokazali su da samo dvije dimenzije ličnosti, prijatnost i neuroticizam, imaju univarijatno dejstvo na ukupno zado- voljstvo trenerskim poslom. Rezultati analize kovarijanse naglašavaju da su tri dimenzije ličnosti: prijatnost, savjesnost i neuroticizam, statistički značajni prediktori pojedinih aspekata zadovoljstva trenerskim poslom. $\mathrm{Na}$ osnovu statističke značajnosti Beta koeficijenata konstatovano je da je dimenzija ličnosti prijatnost značajna za predikciju aspekta zadovoljstva posla napredovanje, dok su dvije osobine ličnosti (prijatnost i neuroticizam) značajni prediktori za aspekte zadovoljstva poslom kao što su: rukovođenje, saradnici, priroda posla i komunikacije. To ukazuje na činjenicu da će treneri sa pozitivnim vrijednostima na skali prijatnosti i negativnim rezultatima na skali neuroticizma dovesti na viši nivo navedene aspekte zadovoljstva trenerskim poslom. Takođe, osobina ličnosti savjesnost značajan je prediktor aspekata zadovoljstva trenerskim poslom kao što su: saradnici, beneficije i nagrađivanje. Osim toga, zaključeno je i to da prediktorske varijable pol i radni staž trenera u klubu, kao i aspekti trenerskog posla plate i radne procedure, nisu statistički značajni za predikciju. Zanimljivo je i to da se dimenzija ličnosti ekstraverzija nije ispoljila kao statistički značajan prediktor zadovoljstva trenerskim poslom, bez obzira na to što su Džadž i saradnici (Judge et al., 1999, 2002) utvrdili da je ona najbitnija prediktorska varijabla.

$\mathrm{U}$ ovom istraživanju, dobijeni rezultati u sistemu prediktorskih varijabli dimenzija ličnosti modela „Pet velikih“ i kriterijuma zadovoljstva trenerskim poslom u skladu su sa nalazima Matanovićeve (2009).

Dobijeni rezultati interpretirani su u kontekstu dosadašnjih saznanja o osobinama ličnosti, pola i radnog staža, i zadovoljstva trenerskog posla. Provjerom najznačajnijih teorijskih pristupa postavljena je osnova za nadogradnju novih saznanja o karakteristikama ovog složenog fenomena u trenerskoj (fudbalskoj, košar- 
kaškoj, odbojkaškoj i rukometnoj) populaciji. Ovim istraživanjem dat je doprinos psihologiji sporta kao naučnoj disciplini, odnosno cjelovitijem razumevanju predviđanja dimenzija ličnosti i zadovoljstva nekim pojavnim oblicima trenerskog posla, a samim tim i plodonosnije implikacije na sportsku praksu. Dobijeni rezul- tati predstavljaju referentnu tačku šireg longitudinalnog istraživanja trenerske populacije i u drugim sportovima u kojem će dobijene nalaze biti moguće sagledati u kontekstu predviđanja aspekata zadovoljstva trenerskim poslom na osnovu osobina ličnosti modela „Pet velikih“.

Ključne riječi: sportski treneri, Big Five model, zadovoljstvo trenerskim poslom. 